\title{
The Relationship Between Child Nurturing Pattern, Family Support, and Language Competence in Children Aged 5-6 Years with Auditory Disorder
}

\author{
Dewi Tirtawati'), Nunuk Suryani²), Rita Benya Adriani') \\ ${ }^{1)}$ School of Health Polytechnics Surakarta \\ 2)Faculty of Teaching and Educational Sciences, Universitas Sebelas Maret
}

\begin{abstract}
Background: Hearing is one of the important senses for human that functions as a communication tool and education. Lack of hearing ability in children may hinder development and lead to problem in language and speaking ability. In turn it may affect academic achievement. Hearing disorder therefore needs to be detected early. This study aimed to determine the relationship between child nurturing pattern, family support, and language competence in children aged 5-6 years with auditory disorder.

Subjects and Method: This was an analytic and observational study with cross sectional design. It was conducted at "Jala Puspa" Children Observation Garden (Taman Observasi Anak "Jala Puspa") Dr. Ramelan Navy Hospital, Surabaya, East Java. A total sample of 40 children aged 5-6 years with their parents were selected for this study by simple random sampling. The dependent variable was language competence. The independent variables were child nurturing pattern and family support. The data were collected by a set of questionnaire, and were analyzed by logistic regression.

Results: There were positive relationship between nurturing pattern $(\mathrm{OR}=10.05 ; 95 \% \mathrm{CI}=1.85$ to $54.73 ; \mathrm{p}=0.008)$, family support $(\mathrm{OR}=6.76 ; 95 \% \mathrm{CI}=1.36$ to $33.51 ; \mathrm{p}=0.019)$, and language competence.

Conclusion: Nurturing pattern and family support have positive relationship with language competence.
\end{abstract}

Keywords: child nurturing pattern, family support, language competence, auditory disorder

\section{Correspondence:}

Dewi Tirtawati. School of Health Polytechnics, Surakarta. Email: tirta.dewi@yahoo.co.id.

\section{BACKGROUND}

Hearing is one of the important senses for humans, functioning as a means of communication and education. Less hearing in children is due to congenital deafness. Congenital deafness, according to the National Committee for Hearing and Deafness, is a deafness that occurs in infants due to factors that affect pregnancy and at birth (Nugroho et al., 2012).

Less hearing in children results in delays and difficulties in language development and speech (Watkin et al., 2007). Disorders of language delay and talk to children are increasing rapidly. Some reports say the incidence of speech impairment ranges from $5-10 \%$ in school children (Sari et al., 2015).

The prevalence of language development delay in Indonesia has never been extensively studied, especially in children with hearing loss. The constraints are in determining the criteria for late language development. Data in the RSCM Medical Rehabilitation Department in 2006 of 1,125 number of pediatric patient visits contained $10.13 \%$ of children diagnosed with late speech and language. Whereas in Sardjito General Hospital Yogyakarta, the prevalence of language developmental delay and 
child talk in speech therapy medical rehabilitation (speech therapy) in 2011, children who experienced dislogia amounted to 235 children, disaudia of 25 children, dysglosia of 3 children, dislalia of 8 children, dysarthria of 17 children, dysphagia of 3 children, stuttering of 3 children, dysfonia of 1 child (Listyowati, 2012).

Children who experience speech language delay gifted due to hearing loss are at risk of having learning difficulties, difficulty reading and writing and will lead to less academic achievement as a whole, this can continue into young adulthood. Furthermore, adults with low academic achievement due to language speech delay will experience behavioral problems and psychosocial adjustment (Sunani, 2013). Delays in language development also affect the social personal life, even the ability of obstacles to work later (Vincer et al., 2005).

Parenting patterns influence the development of language and children's speech. Parents with authoritarian parenting tend to limit love and use harsh punishment so that children obey parental orders. Parenting with permissive types of parents tends to give children freedom to do everything. The democratic type of parenting provides freedom and fosters children's independence but it is monitored. Differences in parenting applied by parents to children can affect children's cognitive and language development, where one parent must be able to determine the right parenting by considering the needs and conditions of the child (Candrasari, 2014).

Handling language delay requires a long time and good cooperation from parents. Some children do not get treatment properly until the development problem becomes something that cannot be handled or has a significant impact on other things. Language delay is often accompanied by other disorders according to the disease such as hyperactivity, strange behavior, difficult to work with, so the handling must begin by improving its behavior (Sunani, 2013).

The formulation of the problem in this study is: "Is there a relationship of parenting parents with language development in children with hearing loss?, is there a social support relationship with language development in children with hearing loss?, and is there a relationship between parenting and support social with language development in children with hearing loss? "

The aim of this study is to determine the relationship between parents' patterns and family support with language skills in 5-6 year old hearing impaired children in Jala Puspa RSAL Children's Observation Park of Dr. Ramelan Surabaya.

\section{SUBJECTS AND METHOD \\ 1. Study Design \\ This was an analytic observational study with cross sectional design. Conducted at "Jala Puspa" Children Observation Garden (Taman Observasi Anak "Jala Puspa”) Dr. Ramelan Navy Hospital, Surabaya, East Java}

\section{Population and Sampling}

The population of this study were parents who had children aged 5-6 years who examined children with hearing loss in Jala Puspa RSAL Children's Observation Park Dr. Ramelan Surabaya is 247 children. The sampling technique used is simple random sampling with the number of study subjects amounting to 40 mothers who have children with hearing loss.

\section{Study Variabel}

The variables in this study consisted of independent variables (parenting and family support), and the dependent variable was the language ability of children with hearing loss. 


\section{Data Analisys}

Data collection tools are questionnaires and literature studies. Data analysis was conducted using logistic regression.

\begin{tabular}{|c|c|c|c|c|}
\hline \multicolumn{5}{|c|}{ RESULTS } \\
\hline \multirow{6}{*}{\multicolumn{5}{|c|}{$\begin{array}{l}\text { 1. Characteristic of the study subjects } \\
\text { The characteristics of study subjects were } \\
\text { divided into two data groups namely conti- } \\
\text { nuous and categorical data. Table } 1 \text { showed } \\
\text { that the study subjects were parents of } \\
\text { children with hearing impairment with } \\
\text { parenting and average family support. } \\
\text { Table 1. Characteristics of continuous } \\
\text { data samples }\end{array}$}} \\
\hline & & & & \\
\hline & & & & \\
\hline & & & & \\
\hline & & & & \\
\hline & & & & \\
\hline Variable & Min. & Max. & Mean & \\
\hline Pare & 109.0 & 148.0 & & \\
\hline $\begin{array}{l}\text { Family } \\
\text { support }\end{array}$ & 24.0 & 48.0 & & \\
\hline
\end{tabular}

Table 2 showed that most mothers were SHS graduates (35.0\%), housewife (52.5\%), and a good children's language ability (52.5\%).
Table 2. Characteristics of categorical data samples

\begin{tabular}{lcc}
\hline \multicolumn{1}{c}{ Variable } & n & \% \\
\hline Education & & \\
Primary school & 6 & 15.0 \\
Junior high school & 11 & 27.5 \\
Senior high school & 14 & 35.0 \\
University & 9 & 22.5 \\
Occupation & & \\
Housewife & 21 & 52.5 \\
Private work & 14 & 35.0 \\
Civil servant & 5 & 12.5 \\
Children's language & & \\
Good & 21 & 52.5 \\
Poor & 19 & 47.5 \\
\hline
\end{tabular}

\section{Analysis Bivariat}

Table 3 showed that there was a relationship between parenting style and child language skills $(\mathrm{OR}=10.29 ; \mathrm{p}=0.001)$. Parents with good parenting style increased child language skills. Table 3 shows that there was a relationship between family support and child language skills $(\mathrm{OR}=$ 6.93; $\mathrm{p}=0.005$ ). Strong family support increased likelihood of child language skill.

Table 3. The results of bivariate analysis

\begin{tabular}{lcccc}
\hline \multirow{2}{*}{ Independent variables } & \multicolumn{2}{c}{ Language development } & \multirow{2}{*}{ OR } & p \\
\cline { 2 - 3 } \cline { 2 - 4 } Family support & Poor & Good & & \\
Weak & & 6 & 6.93 & 0.005 \\
Strong & 13 & 16 & & \\
Parenting style & 5 & 7 & 10.29 & 0.001 \\
Poor & 12 & 18 & & \\
Good & 3 & & \\
\hline
\end{tabular}

\section{Multiple Logistic Regression}

Table 3. Multiple Logistic Regression Analysis

\begin{tabular}{lcccc}
\hline \multirow{2}{*}{ Independent Variables } & \multirow{2}{*}{ OR } & \multicolumn{2}{c}{ 95\% CI } & p \\
\cline { 3 - 4 } Nurturing Pattern & 10.05 & Lower Limit & Upper Limit & 0.008 \\
Family Support & 6.76 & 1.85 & 54.73 & 0.019 \\
-2 log likelihood 38.55 & & & 33.51 & \\
Nagelkerke $\mathrm{R}^{2} 45.8 \%$ & & & & \\
\hline
\end{tabular}

The results of the calculation of multivariate analysis by using multiple logistic regres- sion to determine the relationship between nurturing and family support with the 
development of children's language can be seen in Table 3 .

Good parenting style was positively associated with child language skill. Good parenting style increased child language skill and it was statistically significant (OR= 10.05; $95 \% \mathrm{CI}=1.85$ to $54.73 ; \mathrm{p}=0.008)$.

Family support was positively associated with child language skill. Strong family support increased child language skill and it was statistically significant $(\mathrm{OR}=$ $6.76 ; 95 \% \mathrm{CI}=1.36$ to $33.51 ; \mathrm{p}=0.019)$.

The score of Negelkerke $\mathrm{R}^{2}$ was $45.8 \%$, this mean that both of the free variables (parenting and family support) could explain children's language skills by $45.8 \%$ and the rest $54.2 \%$ was explained by other factors outside the study model.

\section{$\frac{\text { DISCUSSION }}{\text { 1. The relationship between nurtu- }}$ ring patterns and child language skill}

The result of this study showed that that there was a relationship between nurturing and children's language skills which was statistically significant with $(\mathrm{p}=0.008)$, the better the nurturing applied by parents to their children, the better the children's language skills. This result supported a study done by Yani and Wurandiati (2012) which stated that there was a significant relationship between nurturing pattern and personal social, motor, and language development of preschoolers.

Parenting was an important factor in shaping character, personality, emotional intelligence, self-concept formation, and the cultivation of values for children to be able to adjust to the surrounding environment so that the children can be independent, grow, and develop in a healthy and optimal way. Latifah et al. (2009) stated that each family who implement the nurturing process aimed to optimize their children's growth and development holistically. Nurturing patterns played an important role because the family was the first communication in which the children would be educated and shaped by their personal characters. Parents who can provide good examples would also have a good impact, and vice versa.

According to Sujiono (2005), parenting was reflected in two dimensions of parental behavior. The first dimension was the level and type of control carried out by parents on their children's behavior, on the one side, there were parents who controlled and very demanded to their children, and on the other hand, there were parents who never demand and rarely control their children. The second dimension was related to the the involvement of parents and their responsiveness to children, on the other hand, there were parents who were relatively not involved to their children and sometimes they seem to ignore their children.

Parents have their own ways and patterns in nurturing and guiding their children. The method and pattern would certainly differ from one family to another. Nurturing was an illustration of the attitude and behavior of parents and children in interacting and communicating during nurturing activities. In providing this care, parents would give attention, rules, discipline, gifts, and punishment, as well as responses to the wishes of their children.

The attitudes, behavior, and habits of parents were always seen, assessed, and imitated by their children who were consciously or unconsciously impregnated and became habits to their children. This would affect the child's development (Muryanti, 2013). 
Journal of Maternal and Child Health (2016), 1(3): 188-194

https://doi.org/10.26911/thejmch.2016.01.03.06

\section{The relationship between family support and child language skill}

The result of this study showed that that there was a relationship between family support and children's language skills which was statistically significant with $(\mathrm{p}=$ o.019), the stronger the family support received by the mothers, the better the children's language skills.

The result of this study supported a study done by Suryanto et al. (2014) which stated that family roles and social support affected the process of growth and development, it showed that family empowerment was proven to be able to improve the development of toddlers on personal social, language, fine motoric, and gross motoric indicators (each with the score of $\mathrm{p}<0.001$ ). It can be concluded that an enhancement in the role of family and social support could give a positive effect on the growth and development of personal social, language, and motoric in toddlers.

Family support according to Francis and Satiadarma (2004) was the helps received by one family member from another family member in order to carry out the functions in a family. Existing study found that social support from the family was the most effective aspect in reducing the burden on women while social support from the workplace was more effective for men.

The importance of social support for the family was also expressed by Holahan and Moos who found that social support from the family had more effect on the mood compared to social support from the work environment for women (Huda, 2012).

Family social support was a source of emotional, informational or assistance provided by people around individuals to deal with every problem and crisis that occurred in everyday life. Therefore, family members who got full support from other family members would be more motivated to do something, in this case was facing the problem of language skills among children (Kail and Cavanaug, 2000).

The family was the first social group in human life where individuals learned and expressed themselves as social beings. In the family, individuals learn to pay attention to the wishes of others and work together. The experiences of interacting in the family also determined their behavior toward other people outside the family, including neighbors in their neighborhood and friends. The family could be the main supporter for someone in finding the quality and quantity of assistance that they got (Huda, 2012).

Limitations in this study were: This study was only carried out on children aged 5-6 years old in Jala Puspa Children's Observation Park so that the results of this study cannot be generalized in other places and only limited to patients who visited Dr. Ramelan Hospital, Surabaya. The study instrument used was only questionnaire to explore the data about nurturing and family support variables so that the researcher did less observation and in-depth interviews with mothers to see the parenting applied to their children.

The conclusions in this study were: there was a positive relationship between nurturing and language skills in children which was statistically significant (OR= 10.05; 95\% CI= 1.85 to $54.73 ; \mathrm{p}=0.008$ ), and there was a positive relationship between family support and language skills in children which was statistically significant $(\mathrm{OR}=6.76 ; 95 \% \mathrm{CI}=1.36$ to $33.51 ; \mathrm{p}=$ o.019).

The implication in this study was that theoretically, this study revealed that there was an effect of nurturing and family support on language skills in children with 
auditory disorder. This can be confirmed that the theory of Hurlock (2006) about the factors that affect the language ability was valid.

Practical implication of the result was that language development in children with auditory disorder was affected by several factors including nurturing and family support. Therefore, it could be used by health practitioners, especially speech therapy practitioners in providing therapy to combine nurturing and family support factors in order to achieve the expected goals.

\section{REFERENCES \\ Chandrasari JP (2014). Hubungan Pola Asuh Orang Tua dengan Perkem- bangan Bahasa Anak Prasekolah Bahasa Anak Prasekolah di RA Semai Benih Bangsa Al-Fikri Manca Bantul. Naskah Publikasi. Yogyakarta: Pro- gram Studi Ilmu Keperawatan Seko- lah Tinggi Ilmu Kesehatan 'Aisyiyah Yogyakarta.}

Francis S (2004). Pengaruh Dukungan Keluarga terhadap Kesembuhan Ibu yang Mengidap Kanker Payudara. Jurnal Ilmiah Psikologi. ARKHE. Th. 9/no.01/2004.

Huda N (2012). Kontribusi Dukungan Sosial terhadap Kepuasan Hidup, AFEK Menyenangkan dan Afek tidak Menyenangkan pada Dewasa Muda yang Belum Menikah, Jurnal Fakultas Psikologi Universitas Gunadarma.

Hurlock (2006). Perkembangan Anak. Jakarta: Erlangga.

Kail C (2000). Human-Development: A Life-Span View. America: Wadsworth.

Listyowati D (2012). Hubungan Antara Tingkat Pengetahuan dan Sikap Ibu Tentang Stimulasi Bahasa dengan Perkembangan Bahasa Anak Usia 1-3
Tahun di PAUD Mekar Sejati Janti Catur Tunggal Depok Sleman Yogyakarta. Naskah Publikasi. Yogyakarta: Program Studi S1 Ilmu Keperawatan Fakultas Ilmu Kesehatan Universitas Respati Yogyakarta.

Muryanti, Purnaningrum WD, Tirtawati D (2013). Peran Pola Asuh Orang Tua dalam Kemampuan Bahasa Anak Usia 4-5 Tahun. Jurnal Terpadu Ilmu Kesehatan, 3: 172-174

Nugroho DA, Zulfikar, Muyassaroh (2012). Kemampuan Auditorik Anak Tuli Kongenital Derajat Sangat Berat dengan dan Tanpa Alat Bantu Dengar. Medica Hospitalia, 1 (2): 80-82.

Sari SNL, Memy YD, Ghanie A (2015). Angka Kejadian Delayed Speech Disertai Gangguan Pendengaran pada Anak yang Menjalani Pemeriksaan Pendengaran di Bagian Neurootologi IKTHT-KL RSUP Dr.Moh. Hoesin. Jurnal Kedokteran dan Kesehatan. 2(1): 121-127.

Sujiono (2005). Bagaimana Bersikap Pada Anak Agar Anak Prasekolah Anda Bersikap Baik. Jakarta: Gramedia Pustaka Utama.

Sunanik (2013). Pelaksanaan Terapi Wicara dan Terapi Sensori Integrasi pada Anak Terlambat Bicara, Jurnal Pendidikan Islam, 7 (1): 19-44.

Suryanto S, Purwandari H, Mulyono WA (2014). Dukungan Keluarga dan Sosial Dalam Pertumbuhan dan Perkembangan Personal Sosial, Bahasa dan Motorik Pada Balita di Kabupaten Banyumas. Jurnal Kesehatan Masyarakat. 10(1): 103-109.

Vincer MJ, Cake H, Graven M, Dodds L, McHugh S, Fraboni T (2005). A Population-Based Study to Determine The Performance of the Cognitive Adaftive Test/Clinical Linguistic and 
Journal of Maternal and Child Health (2016), 1(3): 188-194

https://doi.org/10.26911/thejmch.2016.01.03.06

Auditory Milestone Scale To Predict The Mental Developmental Index at 18 Months on the Bayley Scale Of Infant Development-II in Very Preterm Infants. Pediatric. 1(1): 864-7.

Watkin P, MacCann D, Law C, Mullee M, Petrou S, Stevenson J, Worsfold S, Yuen HM, Kennedy C (2007). Language Ability in Children With Permanent Hearing Impairment: The
Influence of Early Management and Family Participation. Pediatrics. 120(3): 694-701.

Yani LY, Wurandiati E (2012). Hubungan Pola Asuh Orang Tua dengan Perkembangan Personal Sosial, Motorik dan Bahasa Anak Prasekolah di PAUD AlHidayah. Mojokerto: Prodi D III Kebidanan STIKES Bina Sehat PPNI Mojokerto. 